\title{
Penerapan Model Pembelajaran Kooperatif Tipe NHT (Numbered Head Together) Sebagai Upaya Meningkatkan Prestasi Belajar Seni Budaya
}

\section{Nengah Puspahita*}

SMA Negeri 1 Penebel

\section{A R T I C L E I N F O}

Article history:

Received 19 August 2019

Received in revised form

30 September 20189

Accepted 10 October 2019

Available online 29

November 2019

\section{Kata Kunci:}

NHT (Numbered Head

Together) prestasi belajar

Seni Budaya

Keywords:

NHT (Numbered Head

Together)learning

achievement in Art and Culture

\begin{abstract}
A B S T R A K
Penelitian perbaikan pembelajaran ini dilaksanakan bertujuan untuk meningkatkan prestasi belajar Seni Budaya melalui model pembelajaran kooperatif tipe NHT (Numbered Head Together) tahun pelajaran 2018/2019 di Kelas XII IPS 1 SMA Negeri 1 Penebel yang berjumlah 24 siswa. Jenis penelitian ini adalah penelitian tindakan kelas yang yang dilakukan dalam dua siklus dan ditiap siklusnya ada empat tahapan yaitu, perencanaan, tindakan, observasi, dan refleksi. Metode pengumpulan datanya menggunakan analisis deskriptif kualitatif dan kuantitatif. Berdasarkan hasil penelitian terjadi penigkatan persentase ketuntasan belajar di kelas dari 37,50\% pada prasiklus menjadi $66,66 \%$ pada siklus pertama, dan meningkat menjadi $91,66 \%$ pada siklus kedua. Dan terjadi peningkatan juga pada rata-rata prestasi belajar Seni Budaya siswa dari 63,12 pada tahap prasiklus, menjadi 69,79 pada siklus pertama, dan 76,45 pada siklus kedua.
\end{abstract}

\section{A B S T R A C T}

This learning improvement study was carried out aimed at improving the learning achievements of Arts and Culture through the cooperative learning model of the NHT (Numbered Head Together) type in the 2018/2019 academic year in Class XII IPS 1 of SMA Negeri 1 Penebel, totaling 24 students. This type of research is a classroom action research conducted in two cycles and in each cycle there are four stages namely, planning, action, observation, and reflection. The data collection method uses descriptive qualitative and quantitative analysis. Based on the results of the study an increase in the percentage of mastery learning in class from $37.50 \%$ in the pre-cycle to $66.66 \%$ in the first cycle, and increased to $91.66 \%$ in the second cycle. And there was also an increase in the average learning achievement of Arts and Culture students from 63.12 in the pre-cycle stage, to 69.79 in the first cycle, and 76.45 in the second cycle. 


\section{Pendahuluan}

Pendidikan merupakan aspek penting bagi pengembangan sumber daya manusia. Pendidikan juga diyakini mampu menanamkan pengalaman bagi semua orang untuk mempelajari pengetahuan dan keterampilan sehingga dapat diperoleh manusia yang produktif.Salah satu hal yang paling mendasardalam dunia pendidikan adalah bagaimana usahauntuk menginovasi proses pembelajaran sehingga memperoleh hasil yang maksimal.

Pelaksanaan pembelajaran di SMA menuntut banyak inovasi dalam pelaksanaan proses pembelajaran dengan memanfaatkan fasilitas yang tersedia di lingkungan sekitar sebagai sarana belajar bagi siswa yang dapat menyenangkan. Namun, pada kenyataannya masih banyak sarana dan prasarana yang ada di lingkungan sekitar tempat belajar belum dapat dimanfaatkan dengan maksimal, karena berbagai alasan seperti kurangnya waktu belajar atau kurangnya persiapan pada penguasaan fasilitas belajar.

Proses pembelajaran di sekolah tidak hanya pengembangan dalam aspek kognitif (pengetahuan) saja melainkan juga melalui aspek sosial. Aspek sosial dapat dimulai dari cara siswa belajar interaksi antar siswa dan dilanjutkan dengan pengembangan aspek kognitif melalui salah satu pembelajaran yaitu Seni Budaya BNSP (2006) menyatakan Seni Budaya mengkaji seperangkat peristiwa, fakta, konsep, dan generalisasi yang berkaitan dengan isu sosial. Dewasa ini siswa SMA, termasuk di SMA Negeri 1 Penebel mengalami kesulitan dalam mempelajari mata pelajaran Seni Budaya. Hal ini terbukti dari hasil belajar siswa, sebagian besar memperoleh nilai kurang memuaskan atau di bawah rata-rata Kriteria Ketuntasan Minimal (KKM). Begitupun dalam proses pembelajaran berlangsung, siswa jarang mengajukan pertanyaan atau memberi tanggapan dan menjawab pertanyaan yang diajukan guru. Dengan kata lain siswa tersebut pasif, tidak mau bertanya dan tidak.

Ada beberapa faktor penyebab ketidakmampuan siswa dalam pembelajaran Seni Budaya yaitu rendahnya motivasi siswa, model pembelajaran yang diterapkan guru kurang inovatif, serta minimnya penggunaan media pembelajaran. Motivasi adalah faktor internal yang ada dalam diri siswa. Untuk meningkatkan motivasi tersebut dapat ditingkatkan dengan penerapan model-model pembelajaran yang inovatif sehingga siswa termotivasi dalam mengikuti proses pembelajaran.

Salah satu model pembelajaran yang dapat diterapkan ialah model pembelajaran kooperatif tipe NHT (Numbered Head Together). Pembelajaran kooperatif (cooperative learning) adalah model pembelajaran yang berfokus pada penggunaan kelompok kecil siswa untuk bekerja sama dalam memaksimalkan kondisi belajar untuk mencapai tujuan belajar (Nurhadi, dkk 2004:112).Bukan pembelajaran kooperatif jika siswa duduk bersama dalam kelompok-kelompok kecil dan seluruh kelompok tidak aktif. Pembelajaran kooperatif menekankan pada kehadiran teman sebaya yang berinteraksi antar sesamanya sebagai sebuah tim dalam menyelesaikan atau membahas sebuah masalah

Model pembelajaran kooperatif tipe NHT (Numbered Head Together) atau penomoran berpikir bersama adalah jenis pembelajaran kooperatif yang dirancang untuk mempengaruhi pola interaksi peserta didik. Dalam pengertian lain (Numbered Head Together) adalah metode belajar dengan cara setiap peserta didik diberi nomor dan dibuat suatu kelompok, kemudian secara acak, guru memanggil nomor dari peserta didik Hamdani (2010:89).

Penerapan model pembelajaran kooperatif tipe NHT bertujuan untuk mengetahui peningkatan hasil belajar yang diharapkan. Selain itu siswa bisa saling belajar bekerja sama dan saling membantu untuk memahami pelajaran yang belum dimengerti sehingga hasil belajar siswa dapat lebih baik. Oleh karena itu kita harus menerapkan model yang lain yang lebih mendorong keaktifan anak didik.

Dari uraian yang telah disampaikan, untuk meningkatkan hasil belajar dan aktivitas belajar siswa di Kelas XII IPS 1 SMA Negeri 1 Penebel, maka akan di lakukan penelitian perbaikan pembelajaran dalam bentuk penelitian tingdakan kelas (PTK) dengan judul "Penerapan Model Pembelajaran Kooperatif NHT (Numbered Head Together) Sebagai Upaya Meningkatkan Prestasi Belajar Seni Budaya siswa Kelas XII IPS 1 SMA Negeri 1 Penebel semester II tahun pelajaran 2018/2019"

Aspek penting bagi pengembangan sumber daya manusia. Pendidikan juga diyakini mampu menanamkan pengalaman bagi semua orang untuk mempelajari pengetahuan dan keterampilan sehingga dapat diperoleh manusia yang produktif.Salah satu hal yang paling mendasardalam dunia pendidikan adalah bagaimana usahauntuk menginovasi proses pembelajaran sehingga memperoleh hasil yang maksimal.

Pelaksanaan pembelajaran di SMA menuntut banyak inovasi dalam pelaksanaan proses pembelajaran dengan memanfaatkan fasilitas yang tersedia di lingkungan sekitar sebagai sarana belajar bagi siswa yang dapat menyenangkan. Namun, pada kenyataannya masih banyak sarana dan prasarana yang ada di lingkungan sekitar tempat belajar belum dapat dimanfaatkan dengan maksimal, karena 
berbagai alasan seperti kurangnya waktu belajar atau kurangnya persiapan pada penguasaan fasilitas belajar.

Proses pembelajaran di sekolah tidak hanya pengembangan dalam aspek kognitif (pengetahuan) saja melainkan juga melalui aspek sosial. Aspek sosial dapat dimulai dari cara siswa belajar interaksi antar siswa dan dilanjutkan dengan pengembangan aspek kognitif melalui salah satu pembelajaran yaitu Seni Budaya BNSP (2006) menyatakan Seni Budaya mengkaji seperangkat peristiwa, fakta, konsep, dan generalisasi yang berkaitan dengan isu sosial. Dewasa ini siswa SMA, termasuk di SMA Negeri 1 Penebel mengalami kesulitan dalam mempelajari mata pelajaran Seni Budaya. Hal ini terbukti dari hasil belajar siswa, sebagian besar memperoleh nilai kurang memuaskan atau di bawah rata-rata Kriteria Ketuntasan Minimal (KKM). Begitupun dalam proses pembelajaran berlangsung, siswa jarang mengajukan pertanyaan atau memberi tanggapan dan menjawab pertanyaan yang diajukan guru. Dengan kata lain siswa tersebut pasif, tidak mau bertanya dan tidak.

Ada beberapa faktor penyebab ketidakmampuan siswa dalam pembelajaran Seni Budaya yaitu rendahnya motivasi siswa, model pembelajaran yang diterapkan guru kurang inovatif, serta minimnya penggunaan media pembelajaran. Motivasi adalah faktor internal yang ada dalam diri siswa. Untuk meningkatkan motivasi tersebut dapat ditingkatkan dengan penerapan model-model pembelajaran yang inovatif sehingga siswa termotivasi dalam mengikuti proses pembelajaran.

Salah satu model pembelajaran yang dapat diterapkan ialah model pembelajaran kooperatif tipe NHT (Numbered Head Together). Pembelajaran kooperatif (cooperative learning) adalah model pembelajaran yang berfokus pada penggunaan kelompok kecil siswa untuk bekerja sama dalam memaksimalkan kondisi belajar untuk mencapai tujuan belajar (Nurhadi, dkk 2004:112).Bukan pembelajaran kooperatif jika siswa duduk bersama dalam kelompok-kelompok kecil dan seluruh kelompok tidak aktif. Pembelajaran kooperatif menekankan pada kehadiran teman sebaya yang berinteraksi antar sesamanya sebagai sebuah tim dalam menyelesaikan atau membahas sebuah masalah

Model pembelajaran kooperatif tipe NHT (Numbered Head Together) atau penomoran berpikir bersama adalah jenis pembelajaran kooperatif yang dirancang untuk mempengaruhi pola interaksi peserta didik. Dalam pengertian lain (Numbered Head Together) adalah metode belajar dengan cara setiap peserta didik diberi nomor dan dibuat suatu kelompok, kemudian secara acak, guru memanggil nomor dari peserta didik Hamdani (2010:89).

Penerapan model pembelajaran kooperatif tipe NHT bertujuan untuk mengetahui peningkatan hasil belajar yang diharapkan. Selain itu siswa bisa saling belajar bekerja sama dan saling membantu untuk memahami pelajaran yang belum dimengerti sehingga hasil belajar siswa dapat lebih baik. Oleh karena itu kita harus menerapkan model yang lain yang lebih mendorong keaktifan anak didik.

Pembelajaran kooperatif tipe NHT adalah suatu pembelajaran yang dikembangkan untuk melibatkan lebih banyak siswa dalam menelaah suatu materi pembelajaran, yaitu dengan cara memberikan nomor kepada setiap siswa, kemudian guru mengajukan pertanyaan kepada siswa untuk difikirkan bersama dalam kelompoknya dan guru memanggil salah satu nomor untuk menjawab pertanyaan yang diajukan untuk seluruh kelas. Model pembelajaran kooperatif tipe NHT ini lebih banyak aktivitas siswa dalam menelaah materi yang tercakup dalam suatu pembelajaran dan siswa diajarkan untuk bertanggung jawab terhadap tugas yang diberikan oleh pendidiknya karena pada pembelajaran kooperatif tipe NHT siswa dalam kelompok diberi nomor yang berbeda. Setiap siswa dibebankan untuk menyelesaikan satu soal yang sesuai dengan nomor anggota mereka. Tetapi pada umumnya mereka harus mampu mengetahui dan menyelesaikan semua soal yang diberikan oleh guru. Misalnya siswa dengan nomor urut 1 dalam kelompoknya mempertanggungjawabkan soal nomor 1 begitu pula dengan siswa dengan nomor urut 2 dan seterusnya. Walaupun pada saat persentase mereka bisa ditunjuk untuk mengerjakan soal nomor lain. Namun pada kenyataannya di lapangan menunjukkan bahwa pembelajaran dengan menggunakan model kooperatif tipe NHT masih jarang dilaksanakan guru dalam pembelajaran matematika di kelas. Kenyataan ini juga terjadi dalam pembelajaran matematika di SMP Negeri 1 Balai, sehingga siswa lebih cendrung mendengarkan saja penjelasan guru berkaitan dengan materi yang diberikan, terutama pada materi luas permukaan limas. Selain itu pula diperoleh informasi bahwa siswa sering melakukan kesalahan dalam menyelesaikan soal-soal yang ada dikarenakan siswa kurang dapat mengingat cara penyelesaian masalah luas permukaan limas segiempat yang bervariasi dan kurangnya aktivitas belajar siswa dalam proses pembelajaran berlangsung (Firdaus, 2016). Menurut Dewi, I. G. P (2019) Rata-rata hasil belajar siswa yang dibelajarkan dengan menggunakan model pembelajaran kooperatif tipe NHT $(80,02)$ lebih tinggi.

Dari uraian yang telah disampaikan, untuk meningkatkan hasil belajar dan aktivitas belajar siswa di Kelas XII IPS 1 SMA Negeri 1 Penebel, maka akan di lakukan penelitian perbaikan pembelajaran dalam bentuk penelitian tingdakan kelas (PTK) dengan judul "Penerapan Model Pembelajaran Kooperatif NHT 
(Numbered Head Together) Sebagai Upaya Meningkatkan Prestasi Belajar Seni Budaya siswa Kelas XII IPS 1 SMA Negeri 1 Penebel semester II tahun pelajaran 2018/2019"

\section{Metode}

Penelitian Tindakan Kelas (PTK) ini dilaksanakan di SMA Negeri 1 Penebel yang berlokasi di Kabupaten Gianyar. Jadwal pelaksanaan penelitian ini adalah pada semester Genap tahun pelajaran 2018/2019.

Penelitian ini merupakan penelitian tindakan kelas yang akan dilaksanakan dalam dua siklus. Jika pada siklus pertama hasil belajar Seni Budaya siswa belum memenuhi kriteria keberhasilan, maka berdasarkan hasil refleksi akan dilakukan perbaikan pada siklus selanjutnya. Secara operasional prosedur dasar pengembangan tindakan yang akan dilakukan dapat dijabarkan sebagai berikut.

a. Tindakan daur I: mulai dari definisi masalah, berlanjut ke assessment yang disiapkan, berlanjut ke rumusan hipotesis, berlanjut ke pengembangan untuk tindakan I, lalu implementasi tindakan, evaluasi tindakan berlanjut ke penerapan selanjutnya.

b. Tindakan daur II: mulai dari menentukan kembali masalah yang ada, berlanjut ke assessment yang disiapkan, terus ke pemikiran terhadap munculnya hipotesis yang baru, perbaikan tindakan pada rencana ke 2, pelaksanaan tindakan, evaluasi terhadap semua pelaksanaan dan penerapan.

Untuk penelitian ini penulis memilih rancangan penelitian tindakan yang disampaikan oleh Mc. Kernan seperti terlihat pada gambar berikut.

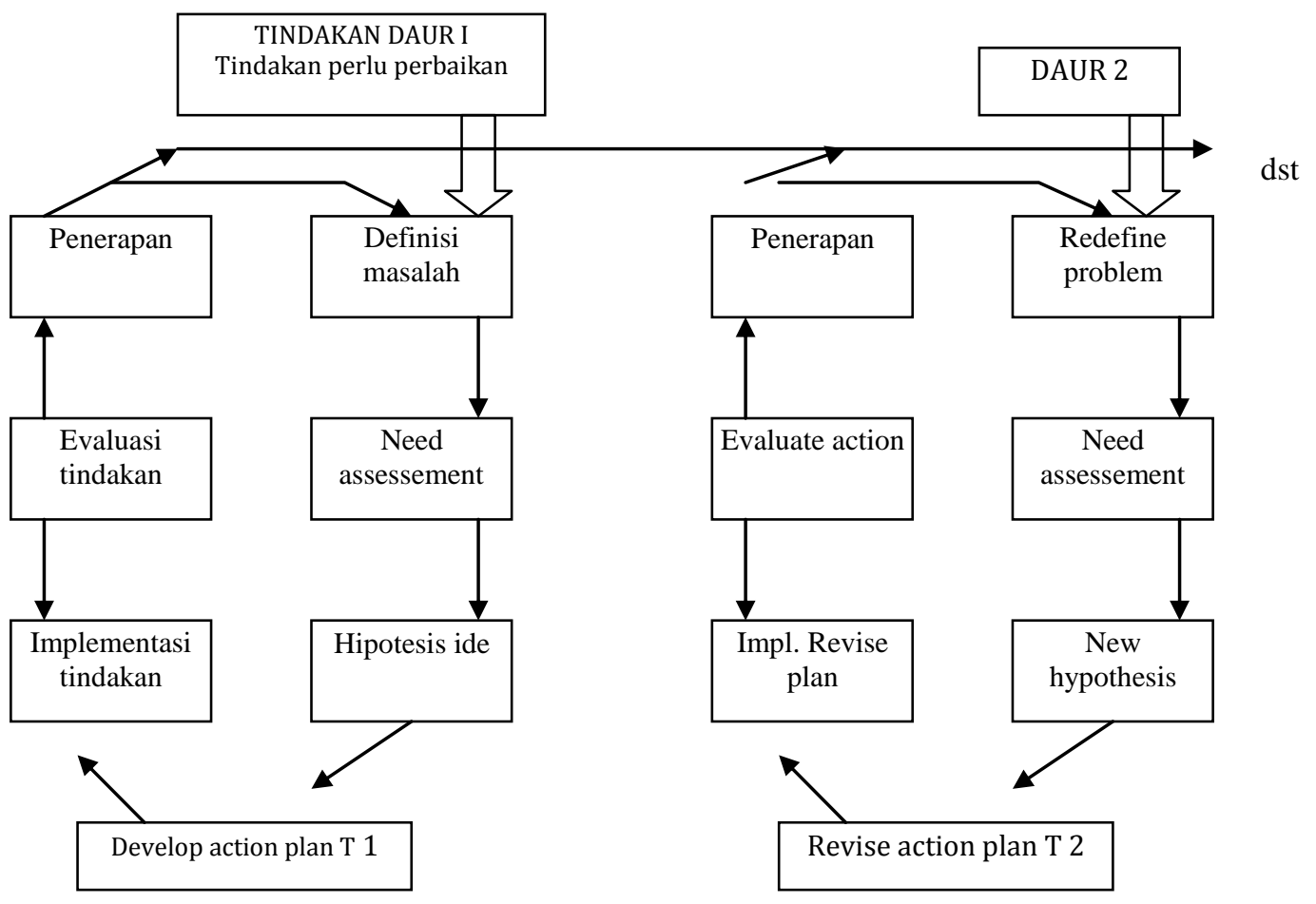

Gambar 1. Penelitian Tindakan Model Mc. Kernan, 1991 (dalam Sukidin, Basrowi, Suranto, 2002: 54)

Prosedur yang dilakukan dengan model ini adalah pada awalnya menemukan kekurangankekurangan yang ada, setelah dianalisis ternyata kemampuan anak dalam pelajaran Seni Budaya masih rendah sehingga dibuat perencanaan, dilanjutkan dengan langkah-langkah tindakan yaitu melatih terus sesuai kaidah pembelajaran di SMA karena penilaian terhadap kemajuan anak harus diupayakan berkesinambungan, begitu juga penilaiannya. Lara Fridani, dkk (2009: 6.6) mengatakan bahwa assesment perkembangan anak dilaksanakan secara terus menerus dan berkesinambungan. Setelah langkah tindakan dimonitor berserta efeknya serta kegagalannya bisa ditemukan, dibuat revisi untuk perencanaan selanjutnya. Demikian terus bergulir sampai penelitian berhasil sesuai indikator yang diusulkan.

Pengumpulan data dalam penelitian ini menggunakan tes prestasi belajar. Tes prestasi belajar berupa tes soal essay. Untuk menganalisis data hasil penelitian ini digunakan metode deskriptif. Untuk data kuantitatif dianalisis dengan mencari mean, median, modus, membuat interval kelas dan melakukan penyajian dalam bentuk tabel dan grafik. 
Indikator keberhasilan penelitian yang diusulkan dalam penelitian ini pada siklus I dan II mencapai nilai rata-rata 75,00 dengan ketuntasan belajar 85\%. dengan KKM yang ditetapkan untuk mata pelarajan Seni Budaya pada SMA Negeri 1 Penebel adalah 70.

\section{Hasil dan Pembahasan}

Pembelajaran Seni Budaya di SMA memberikan pengetahuan dasar dan keterampilan sebagai media pelatihan bagi siswa sebagai warga negara sedini mungkin. Karena pendidikan Seni Budaya tidak hanya memberikan ilmu pengetahuan semata, tetapi berorientasi pada pengembangan keterampilan berpikir kritis, sikap, dan kecakapan-kecakapan dasar siswa yang berpijak pada kehidupan sosial dan kemasyarakatan.

Alma (2003:148) mengemukakan pengertian Seni Budaya sebagai suatu program pendidikan yang merupakan suatu keseluruhan yang pada pokoknya mempersoalkan manusia dalam lingkungan alam fisik, maupun dalam lingkungan sosialnya dan yang bahannya diambil dari berbagai ilmu sosial, seperti geografi, sejarah, ekonomi, antropologi, sosiologi, politik dan psikologi.

Hakikat pembelajaran Seni Budaya (Susanto: 2015;138) adalah untuk mengembangkan konsep pemikiran yang berdasarkan realita kondisi sosial yang ada di lingkungan siswa, sehingga dengan memberikan pendidikan Seni Budaya di harapkan dapat melahirkan warga negara yang baik dan bertanggung jawab terhadap bangsa dan negaranya.

Dalam menciptakan proses pembelajaran seni budaya yang lebih bervariasi dan dapat meningkatkan peran siswa, guru dapat merancang serta menciptakan suasana kelas yang memberikan kesempatan kepada siswa untuk berinteraksi satu dengan yang lainnya. Salah satu model pembelajaran yang dapat digunakan guru adalah model pembelajaran kooperatif. Pembelajaran kooperatif adalah kegiatan pembelajaran dengan cara berkelompok untuk bekerja sama, saling membantu mengkonstruksi konsep, menyelesaikan persoalan, atau inkuiri.

Suyatno (2006:51) mengatakan pembelajaran kooperatif (Cooperative Learning) sesuai dengan sifat manusia sebagai makhluk sosial yang penuh ketergantungan dengan orang lain, mempunyai tujuan dan tanggung jawab bersama, pembagian tugas, dan rasa senasib. Dengan pembelajaran kooperatif siswa dilatih dan dibiasakan untuk saling berbagi (sharing) pengetahuan, pengalaman, tugas, tanggung jawab. Saling membantu dan berlatih berinteraksi-berkomunikasi-sosialisasi karena kooperatif adalah miniatur dari hidup bermasyarakat, dan belajar menyadari kekurangan dan kelebihan masing-masing.

Selanjutnya, Anita Lie 2000 (Isjoni, 2009: 23), mengemukakan "pembelajaran kooperatif dengan istilah pembelajaran gotong-royong, yaitu sistem pembelajaran yang memberi kesempatan kepada peserta didik untuk bekerjasama dengan siswa lain dalam tugas-tugas yang terstruktur". Pembelajaran kooperatif akan berjalan jika sudah terbentuk suatu kelompok yang di dalamnya siswa bekerja secara terarah untuk mencapai tujuan pembelajaran yang sudah ditentukan. Dari beberapa pendapat ahli di atas, dapat disimpulkan bahwa pembelajaran kooperatif ialah suatu model pembelajaran yang mengelompokkan siswa ke dalam kelompok-kelompok kecil yang heterogen terdiri dari 4-6 orang, sehingga memberikan kesempatan kepada siswa untuk belajar mandiri, belajar bekerja sama, belajar bertukar pikiran mengenai tugas-tugasnya untuk mencapai tujuan pembelajaran bersama.

Model pembelajaran kooperatif tipe NHT dikembangkan oleh Spencer Kagan (dalam Anita Lie, 2004: 59) mengemukakan bahwa, "teknik ini memberikan kesempatan kepada siswa untuk saling membagikan ide-ide dan mempertimbangkan jawaban yang paling tepat". Tenik ini juga dapat mendorong siswa untuk meningkatkan semangat kerjasama siswa dan memudahkan dalam menelaah bahan yang tercakup dalam suatu pelajaran dan mengecek pemahaman siswa terhadap isi pelajaran tersebut.

Berdasarkan penelitian yang telah dilakukan dengan menerapkan model pembelajaran kooperatif NHT, didapatkan hasil bahwa: data awal yang diperoleh dengan rata-rata 63,12 menunjukkan bahwa kemampuan siswa dalam mata pelajaran Seni Budaya masih sangat rendah mengingat kriteria ketuntasan belajar siswa untuk mata pelajaran ini di SMA Negeri 1 Penebel adalah 70,00. Dengan nilai yang sangat rendah seperti itu maka peneliti mengupayakan untuk dapat meningkatkan prestasi belajar anak/siswa menggunakan model pembelajaran NHT Akhirnya dengan penerapan model pembelajaran NHT yang benar sesuai teori yang ada, peningkatan rata-rata prestasi belajar anak/siswa pada siklus I dapat diupayakan dan mencapai rata-rata 69,79. Namun rata-rata tersebut belum maksimal karena hanya 16 siswa memperoleh nilai di atas KKM sedangkan yang lainnya belum mencapai KKM. Sedangkan prosentase ketuntasan belajar mereka baru mencapai $66,66 \%$. Hal tersebut terjadi akibat penggunaan metode/model pembelajaran NHT belum maksimal dapat dilakukan disebabkan penerapan model tersebut baru dicobakan sehingga guru masih belum mampu melaksanakannya sesua alur teori yang benar.

Pada siklus ke II perbaikan prestasi belajar siswa diupayakan lebih maksimal dengan peneliti membuat perencanaan yang lebih baik, menggunakan alur dan teori dari model pembelajaran NHT 
dengan benar dan lebih maksimal. Peneliti giat memotivasi siswa agar giat belajar, memberi arahanarahan, menuntun mereka untuk mampu menguasai materi pelajaran pada mata pelajaran Seni Budaya lebih optimal. Akhirnya dengan semua upaya tersebut peneliti mampu meningkatkan prestasi belajar siswa pada siklus II menjadi rata-rata 76,45 dengan presentase ketuntasan mencapai 91,66\%, hal ini menunjukkan terjadinya peningkatan yang sangat signifikan. Upaya-upaya yang maksimal tersebut menuntun pada suatu keberhasilan bahwa model pembelajaran NHT mampu meningkatkan prestasi belajar anak/siswa.

Semua hasil yang diperoleh dari awal, siklus I dan siklus II digambarkan dalam bentuk tabel dan grafik seperti berikut:

Tabel 1. Tabel Data Hasil Belajar Siswa Kelas XII IPS 1 SMA Negeri 1 Penebel

\begin{tabular}{|c|c|c|c|c|c|}
\hline DATA & AWAL & SIKLUS I & SIKLUS II & VARIABEL & \\
\hline Skor Nilai & 1515 & 1675 & 1835 & Hasil Belajar & Seni \\
\hline Rata Rata Kelas & 63,12 & 69,79 & 76,45 & Budaya & \\
\hline $\begin{array}{l}\text { Persentase } \\
\text { Ketuntasan }\end{array}$ & $37,50 \%$ & $66,66 \%$ & $91,66 \%$ & $\begin{array}{l}\text { Dengan } \\
\mathrm{KKM}=70\end{array}$ & \\
\hline
\end{tabular}

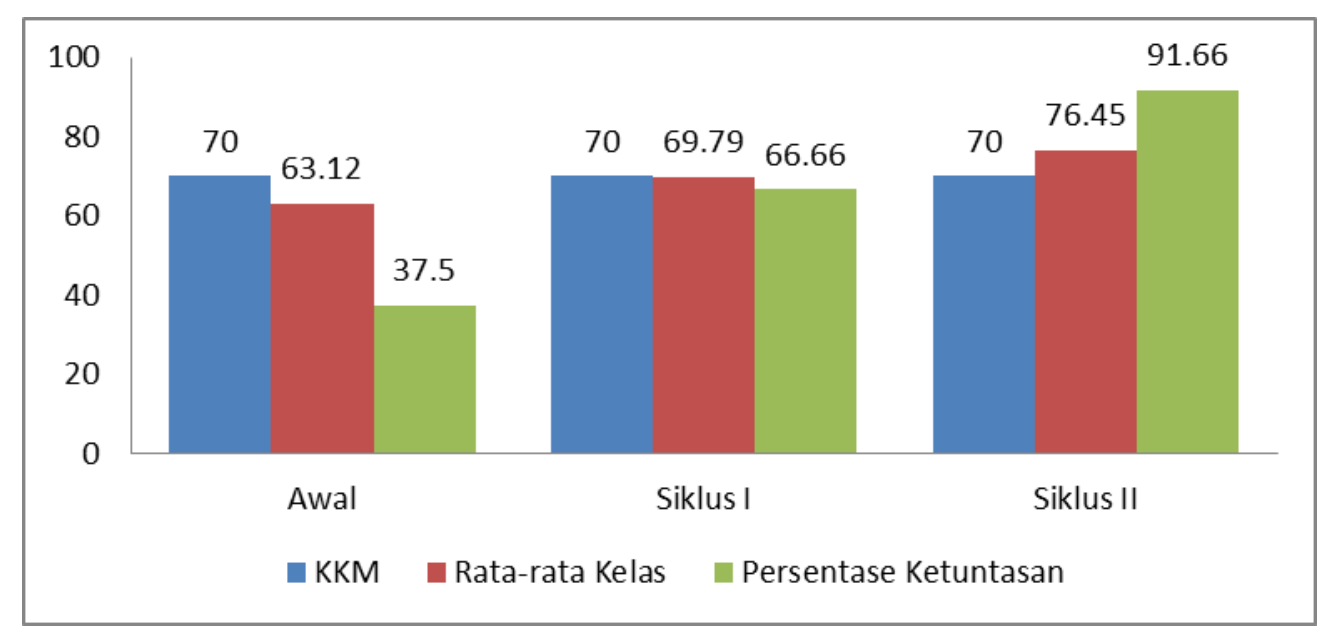

Gambar 2. Grafik Histogram Hasil Belajar Seni Budaya siswa Kelas XII IPS 1 Semester II Tahun Pelajaran 2018/2019 SMA Negeri 1 Penebel

Hasil penelitian ini sejalan dengan hasil penelitian yang dilakukan oleh Sulfani pada tahun 2016 yang berjudul Penerapan Model Pembelajaran Kooperatif Tipe Numbered Head Together (NHT) Untuk Meningkatkan Hasil Belajar Kimia Siswa Kelas XI IPA1 SMA Negeri 3 Watampone (Studi pada Materi Pokok Struktur Atom, Sistem Periodik Unsur dan Bentuk Molekul). Hasil penelitiannya menunjukkan bahwa: hasil belajar kimia siswa setelah menerapkan model pembelajaran kooperatif tipe NHT meningkat dari siklus I ke siklus II untuk materi sturuktur atom, sistem periodik unsur, dan bentuk molekul.

\section{Simpulan Dan Saran}

Penelitian Simpulan yang dapat disampaikan berdasarkan semua hasil analisis data yang telah dilakukan dengan melihat hubungan rumusan masalah, tujuan penelitian, hipotesis tindakan dan semua hasil pembahasan adalah sebagai berikut: 1) Dari data awal ada 15 siswa mendapat nilai dibawah KKM dan pada siklus I menurun menjadi 8 siswa dan siklus II hanya 2 siswa mendapat nilai di bawah KKM, 2) Nilai rata-rata awal 63,12 naik menjadi 69,79 pada siklus I dan pada siklus II naik menjadi 76,45, 3) Dari data awal siswa yang tuntas hanya 9 orang sedangkan pada siklus I menjadi lebih banyak yaitu 16 siswa dan pada siklus II menjadi cukup banyak yaitu 22 siswa.

Paparan di atas membuktikan bahwa model/metode pembelajaran NHT dapat memberi jawaban sesuai tujuan penelitian ini. Semua ini dapat dicapai karena model pembelajaran NHT sangat efektif diterapkan dalam proses pembelajaran yang mengakibatkan siswa aktif, antusias dan dapat memahami materi yang diajarkan sehingga prestasi belajar siswa menjadi meningkat. 


\section{Daftar Rujukan}

Abdurrahman, Mulyono. 1999. Pendidikan bagi Anak Berkesulitan Belajar. Jakarta: Rineka Cipta.

Agung, A.A. Gede. 2010. Penelitian Tindakan Kelas (Teori dan Analisis Data dalam PTK). Makalah disajikan pada Workshop Jurusan PGSMA. Singaraja: Undiksha.

Ahmad Susanto. 2015. Teori Belajar Dan Pembelajaran Disekolah Dasar. Jakarta: Prenada Media.

Aisyah, Siti, dkk. 2008. Perkembangan dan Konsep Dasar Pengembangan Anak Usia Dini. Jakarta: Universitas Terbuka.

Alma, Buchari. 2003. Manajemen Pemasaran dan Pemasaran Jasa. Edisi 2. Bandung: Alfabeta.

Amri, Sofan. 2013. Peningkatan Mutu Pendidikan SMA dan Menengah. Jakarta: PT. Prestasi Pustakaraya.

Anita Lie. 2004. Cooperative Learning: Mempraktekkan Cooperative Learning di. Ruang-Ruang Kelas. Jakarta : PT. Grasindo.

Arikunto, Suharsimi. 2003. Prosedur Penelitian Suatu Pendekatan Praktek. Jakarta: Rineka Cipta.

Basrowi dan Sukidin. 2002. Metode Penelitian Kualitatif Perspektif Mikro. Surabaya. Insan Cendikia.

Dewi, I. G. P., Selamat, I. N., \& Suardana, I. N. (2019). Studi Komparasi Model Pembelajaran Kooperatif Tipe Team Assisted Individualization Dan Tipe Numbered Heads Together Terhadap Hasil Belajar Kimia Pada Topik Struktur Atom. Jurnal Pendidikan Kimia Indonesia, 2(2), 50-58.

Firdaus, Muhamad. 2016. Penerapan Model Pembelajaran Kooperatif Tipe Numbered Heads Together (Nht) Ditinjau Dari Aktivitas Belajar Siswa Kelas Viii Smp. Jurnal Formatif 6(2): 93-99, 2016 ISSN: 2088-351X.

Fridani Lara, Wulan dkk. 2009. Evaluasi Perkembangan Anak Usia Dini. Jakarta : Universitas Terbuka.

Isjoni. 2009. Cooperative Learning Efektivitas Pembelajaran Kelompok. Bandung: Alfabeta.

Sulfani, Ridha. 2016. Penerapan Model Pembelajaran Kooperatif Tipe Numbered Head Together (NHT) Untuk Meningkatkan Hasil Belajar Kimia Siswa Kelas XI IPA1 SMA Negeri 3 Watampone (Studi pada Materi Pokok Struktur Atom, Sistem Periodik Unsur dan Bentuk Molekul). Jurnal Chemica Vo/. 17 Nomor 1 Juni 2016, 1- 13.

Suyatno. 2009. Menjelajah Pembelajaran Inovatif. Sidoarjo: Masmedia Buana Pusaka. 